glutaraldehyde (6.25 per cent). And Lowy and Small (Nature, 227, 46 ; 1970) observed thick ribbon-shaped filaments of myosin in guinea-pig taenia coli muscle. But the muscle had been immersed for $3-4 \mathrm{~h}$ in Ringer's solution at $0^{\circ} \mathrm{C}$, which eliminated the contractile response, before it was fixed conventionally. Now Rosenbluth (J. Cell. Biol., 48, $174 ; 1971)$ reports that after exposure to a solution of trypsin in Ringer's, small intestinal smooth muscle of the toad Bufo marinus contains thick filaments about $250-300 \AA$ in diameter and some 0.5 to $1.0 \mu$ long. Further, some of these filaments have an axial periodicity of $143 \AA$ and they closely resemble aggregates of smooth muscle myosin produced in vitro. In the cells treated with enzymes, however, these thick, presumably myosin filaments are segregated from the thin actin filaments.

Rosenbluth's interpretation of all this, which may not be welcome in all quarters, is that in smooth muscle in vivo the myosin occurs dispersed among the actin filaments in a relatively disaggregated state. And by implication the thick myosin filaments he and others have seen are artefacts of the preparation techniques, which induce aggregation of myosin. It will be interesting to see if such nihilism survives the test of time.

In the same issue of the Journal of Molecular Biology (ibid., 128), Shimada published a series of electron micrographs which illustrate the process of myoblast fusion, the process which apparently gives rise to multinucleated muscle fibres during embryogenesis. Shimada's observations of cultured myoblasts reveal that myoblasts destined to fuse become closely applied. The two cells pinocytose projections from each other's sarcolemmas; tubules and vesicles can then span the two cells and eventually their surface membranes completely disappear at the site of contact so their cytoplasms become confluent. Such fusions occur between pairs of uninucleate myoblasts multi and uninucleate cells and nascent multinucleate myotubes. Clearly, they pose some fascinating questions about the mechanisms of cellular recognition, adhesion and contact, all of which are presumably mediated through the chemistry of the cell surface.

\section{MAMMALS}

\section{Buts in the Aftic}

WITH the exception of rodents (order Rodentia) more species of bats (order Chiroptera) have been recorded than any other order of mammals. And among terrestrial mammals, bats of the genus Myotis in the family Vespertilionidae are surpassed in their distribution only by man. This genus is absent only from the Arctic, subarctic regions and some oceanic islands. But in spite of being relatively accessible to zoologists who care to look for them, surprisingly little is known about the life habits and ecology of bats, and this applies particularly to species living in neotropical regions. Zoologists will therefore be glad of Don E. Wilson's study of the ecology of Myotis nigricans, a small vespertilionid species which is limited to the New World tropics and is locally abundant in the Panama Canal Zone (J. Zool., 163, 1).

Wilson was fortunate in being able to study an easily accessible roost of more than 1,000 individuals in the attic of a laboratory building on Barro Colorado Island. Roosting in buildings is not unusual for this species. In fact, it seems to prefer man-made structures and other disturbed habitats to primary forest, which suggests that it is a relative newcomer to the American tropics. Caves and hollow trees, the two most common roosting sites for bats, are heavily used by many species of phyllostomatid and emballonurid bats and it is possible that if $M$. nigricans entered the tropics after these other species were well established in primary forest it may have been forced to roost in unused areas such as attics and under the eaves of thatched roofs. The theory that this species arrived recently in the tropics is supported further by the bat's food preferences. It is insec- tivorous and it is possible that it finds a larger food supply around cleared areas and human habitations than in primary forest where there are fewer insects between the ground level and up to about $10 \mathrm{~m}$ compared with inside the canopy. Of course, $M$. nigricans may simply have been a rare species before the clearing of forests and the spread of agriculture and human settlements (perhaps because of competition for roost sites) and has only recently increased in numbers.

The daily thermoregulatory activity of $M$. nigricans is interesting. As the tin roof of the laboratory building warms up each afternoon (except in the cooler part of the rainy season from September to December), Wilson noted that the bats break up their roosting clusters under the roof and move down the walls to the floor where there is better air circulation. They then congregate in different corners of the room depending on the time of year and the wind patterns. When under the roof, most of the bats are in one of several clusters, but there are also some solitary roosters. Wilson found that females predominate in the clusters and it is the males which tend to be solitary. When the clusters break up in the hot weather from January to September the sexes therefore mingle on the floor and this is when copulation occurs. No copulation takes place in the latter part of the rainy season

\title{
Salt Layer Beneath the Mediterranean
}

IN next Monday's Nature Physical Science Auzende and his colleagues at the Centre Océanologique de Bretagne, Brest, describe a continuation of their work on the interpretation of diapirs as salt domes, this time in the Mediterranean. Many people have reported the presence of diapirs in this area but have never been able to prove conclusively that they are the result of salt doming. To be sure, the circumstantial evidence for this is strong-notably the presence of sulphur, chalcopyrite and increased salinity in the interstitial waters. But the structures are small (usually less than $2 \mathrm{~km}$ wide) and covered by about $3 \mathrm{~km}$ of sediment which makes them not easily accessible. Auzende and his co-workers have thus extended their indirect observations using the 'Flexotir' deep seismic profiling technique.

They have been able to infer that a salt layer beneath the sediment underlies a great part of the western Mediterranean at least. The bottom of these evaporite deposits appears as a strong reflector, flat or slightly folded, in contrast to the upper boundary which is, as expected, often strongly disturbed by diapirism. Away from the domes, however, the salt layer seems to be more or less uniform in thickness and at a constant level.

The existence of such a salt layer inevitably raises the question of its age. Extension of the continental geology suggests two possibilities here-Triassic or Oligo-Miocene- and both have been offered support at some time or other in connexion with a hypothesized salt layer. Glangeaud et al. (Bull. Soc. Geol. France, 8, 921; 1966), for example, suggested Triassic whereas Ryan (thesis, Columbia Univ., 1969) plumped for Oligocene. Auzende and his colleagues conclude from sediment thickness and tectonic evidence, however, that the layer is, in fact, upper Miocene in age.

All this work was completed and the conclusions drawn before the JOIDES vessel, Glomar Challenger, entered the Mediterranean. But in a footnote Auzende et al. point out that in the meantime salt has been recovered from three holes in the western Mediterranean during Leg XIII of the JOIDES project; and that the upper Miocene age has been confirmed. 